\title{
The Relationship between Linguistic Intelligence and Visual, Auditory, and Kinesthetic Preferences of Iranian EFL Learners
}

\author{
Rashideh Zoghi \\ English Department, Islamic Azad University, Tabriz Branch, Iran
}

\begin{abstract}
Many factors including the learners' individual personality factors and their sociocultural backgrounds, attitudes to learning the new language, intelligence quotient, and personal learning styles and preferences are involved in the process of second/foreign language learning. The present study attempted to examine the relationship between learners' linguistic intelligence and their visual, audio, and kinaesthetic (VAK) preferences by formulating three null hypotheses. In order to test the hypotheses, a total number of 100 Iranian female high school-level EFL learners in Tabriz were selected through cluster sampling. The participants took a linguistic intelligence test and responded to a VAK preference questionnaire to obtain data about their linguistic intelligence and VAK preferences. The statistical analysis of the obtained data led to the rejection of all three null hypotheses indicating a significant relationship between the learners' linguistic intelligence and their VAK preferences. The relationship between linguistic intelligence and auditory preferences turned out to be negative and reverse. These results indicated that in order to increase teaching efficiency, the language educators should try to prepare and use instructional materials suiting the learners' visual, auditory, and kinaesthetic preferences, indicating the need for individualized language instruction. The findings have implications for curriculum developers and syllabus designers as well as educational policy makers.
\end{abstract}

Index Terms - linguistic intelligence, VAK preferences, Iranian EFL learners

\section{INTRODUCTION}

By definition, learning, including learning a foreign language, means, "The process by which change in behaviour, knowledge, skills, etc. comes about through practice, instruction, or experience and the result of such a process." (Richards \& Schmidt, 2002, P. 298). However, learning a foreign language is more than just a boost to your CV or a handy tool for travelling. It will make you smarter, more decisive, and even better in English, says Merritt (2013). Although, there are individual differences across learners in learning a new language (Ellis, 1994), there are other crucial learning factors including internal (age, personality, motivation, experiences, cognition, and native language) and external (curriculum, instruction, culture and status, and access to native speakers) parameters over which learners have no control. Moreover, every human being has got different kinds of intelligences, and we cannot consider anybody as purely intelligent or unintelligent. In fact, the theory of multiple intelligences challenges the traditional notion of intelligence which has been defined in terms of intelligence quotient (IQ) (Christison, 1998; PoYing, 1999; Saeidie, 2007).

Besides, representational systems also known as sensory modalities and abbreviated to VAK is a postulated model from neuro-linguistic programming (NLP) regarding how the human mind supposedly processes and stores information. The central idea of this model is that experience is represented in the mind in sensorial terms, i.e. in terms of five senses. Moreover, we all process information in three distinct ways, these are called: Visual, Auditory, and Kinaesthetic. These are ways we re-present the world through our five senses and how we typically communicate them back to the world. When information reaches our brain, it is given meaning and forms a subjective experience of the world. This is our representation otherwise known as our perception. Although we use all of the representational systems, we tend to have a preference, just like there are people who prefer certain types of food (Ellerton, 2015).Specifically speaking, some learners are labelled as visual learners who learn better by being exposed to visual instructional stimuli; some others prefer learning through hearing, and they are rightly categorized as the learners who have a preference for audio stimuli. Meanwhile there are a third group of learners who have a natural preference for learning through doing activities, and they are labelled as kinaesthetic learners (Najjari, 1996 as cited in Dehghan Harati, 2011). Exploring the VAK preferences of the learners may provide insights for the language educators and teachers in order to be able to match their own teaching methods and techniques to the individual preferences of the learners, leading to more accurate planning and more economical use of the valuable teaching time.

On the other hand, finding the probable link between linguistic intelligence and VAK preferences of the learners may prove to be highly illuminating for language educators generally and second or forging language educators, particularly. The researcher assumes that by identifying VAK preferences of the learners, the language teachers would be in a better 
position to decide on the type of linguistic and non-linguistic stimuli to bring about better learning outcomes for the learners.

Some studies have focused on the role of VAK preferences in learning generally and second or forging language particularly. For example, Farooque, Mustafa, and Mohammad (2014) investigated the learning style preferences of first year undergraduate medical students. The results of this study showed that there was no significant difference in learning preferences between the genders. In a similar study conducted by Marwah, Bhagat, and Kapoor (2015) the learning preferences of undergraduate dental students of a north Indian dental college was investigated. The results showed diversity in learning styles or preferences of the learners. Furthermore, Alavinia and Ebrahimpour (2012) investigated the correlation between emotional intelligence and learning styles of Iranian academic EFL learners. A significant difference was found to be at work with regard to the performance of different genders. Pourhossein (2012) investigated VAK preferences and their effects on English language teaching. The Findings showed that Iranian EFL university students preferred learning style was visual. Finally, Shahi (2009) investigated the relationship between multiple intelligence and learning styles. The results of the study showed that there was a strong correlation between learning styles and multiple intelligences.

Already, some studies have been conducted on both multiple intelligence and VAK preferences of second or foreign languages learners. For example, in Iranian EFL context. Davoudi and Chavosh (2016) conducted a study on the relationship between multiple intelligence and listening self-efficacy among Iranian EFL learners. Some of the studies have attempted to find out either the effect of MI or its relationship with learning language skills and components. For instance, Mohammadi and Mousalou (2012) studied the relevance of emotional and linguistic intelligence to speaking anxiety of EFL learners. Their results showed that there was a correlation between speech anxiety and emotional intelligence (EI). They also found that there was a relationship between speech anxiety and the learner's first language. Furthermore, Sajjadi Rad, Khojasteh and Kafipour (2014) investigated the relationship between multiple intelligences and the writing skill of the medical students in Iran. The mentioned researchers came to the conclusion that there is no significant relationship between the Iranian EFL learners.

A review of related literature indicated that almost no study has ever attempted to focus specifically on the relationship between linguistic intelligence and VAK preferences of Iranian EFL learners at high school level, and the present study was an attempt to fill this gap. Specifically speaking, facing every kind of learners in each class, as a teacher, the researcher decided to conduct this study to classify learners in three groups (VAK) according to their preferences and prepare teaching methods, materials, and lesson plans to meet the needs of each type of learner despite the fact that traditional methods focus just on limited methods and make the lessons boring for almost of learners.

In the present quantitative survey-based correlational study there were two variables, linguistic intelligence and VAK, and the researcher wanted to find out if there is a relationship between linguistic intelligence and VAK preferences. In line with this purpose, the following null hypotheses were proposed:

H01: There is not any significant relationship between linguistic intelligence and visual preferences of Iranian EFL learners?

H02: There is not any significant relationship between linguistic intelligence and auditory preferences of Iranian EFL learners?

H03: There is not any significant relationship between linguistic intelligence and kinesthetic preferences of Iranian EFL learners?

The validity of the assumptions in the mentioned hypotheses was empirically tested through the process described in the following sections.

\section{METHODOLOGY}

\section{Participants}

The population of this study included all female senior high school EFL learners in Tabriz. The sample size was about 100 learners selected through cluster sampling. All the participants were female students studying in state schools and had the same cultural background. Their age ranged from 14 to16. In terms of proficiency level, participants were all placed at lower intermediate level according to their school books (Prospect 3 written by the authorial group of Iran Ministry of Education).

\section{Instruments}

In this quantitative survey-based study VAK preference questionnaire (Appendix II) and linguistic intelligence test (Appendix I) were administered. The linguistic intelligence test included 10 questions which were selected out of 80 questions of Multiple Intelligence questionnaire developed by Gardner (1983). To make the questionnaire comprehensible to the respondents, it was translated into Persian. The questionnaire was originally reviewed by 5 other M.A. colleagues in order to eliminate the faulty items. It was, then, revised, and validated through a pilot study with 20 respondents, which revealed a reliability coefficient of .846 indicating acceptable reliability level. Each item in the questionnaire is ranked as 1-5 in which 1 indicates the lowest interest of the learner and 5 shows the highest interest of him/her.

The VAK questionnaire developed by Victoria Chislett (2005), includes 30 multiple choice questions tagged as A, B, and C (Appendix II). Those who choose mostly A's have a visual learning style, those who choose mostly B's have an 
auditory learning style. Those who choose mostly C's have a kinesthetic learning style. A pilot study with 20 sample respondents was conducted in order to ensure the validity of the questionnaire. The reliability analysis of the questionnaire revealed a reliability level of .887, .910, and .724 for visual, auditory, and kinesthetic preferences questions, respectively.

\section{Procedure}

a. Pilot Study on the Questionnaires for Checking their Validity

A pilot study was conducted with 20 sample respondents in order to ensure the validity of the questionnaire. The reliability analysis of the questionnaire revealed a reliability level of $.887, .910$, and .724 for different VAK indexes of the questionnaire, indicating an acceptable range of reliability. This indicated that the questionnaire was a valid measure of the learners' VAK preferences.

Moreover, the linguistic intelligence test items were reviewed by 5 other colleagues. Then it was piloted with $20 \mathrm{EFL}$ learners at the same high school. The reliability analysis revealed a reliability level of .846 indicating its acceptability. Therefore, the linguistic intelligence questionnaire could be safely used for measuring the participants' linguistic intelligence.

\section{b. The Main Study}

Having selected the respondents through cluster sampling, the already-validated 10-item linguistic intelligence questionnaire was administered to the main participants of the study. The test was administered by the researcher in four classes which included a total number of 100 learners. It took 20 minutes for the respondents to answer the questions. The questionnaire items were in Persian, so the respondents need not much explanation. The respondents were supposed to check the options which best suited them. There were 5 options for each question. The options were tagged as $1,2,34,5$, in which 1 shows the respondents lowest interest, and 5 shows their highest interest. Having finished the responding process, the researcher added up the obtained scores for each participant. The higher the total score, the higher the linguistic intelligence would be.

The VAK questionnaire which includes 30 multiple choice questions, was also given to the same respondents in the next session of the class, and completing it lasted 70 minutes. The researcher translated each item into Farsi whenever it was needed to solve any probable problems. This questionnaire includes a total number of 30 questions each of which has 3 options of as A, B, and C. The respondents were supposed to choose the option which best suited them. After finishing the responding process, the researcher identified the respondents' preference by counting As, Bs, and Cs. Those who chose mostly A's have a visual learning style; those who chose mostly B's have an auditory learning style. Those who chose mostly C's have a kinesthetic learning style.

\section{RESULTS}

\section{Reliability Analysis of the Research Instruments}

In order to examine the reliability of the items in linguistic intelligence test and VAK preferences questionnaire, Cronbach's alpha was used. The results of the reliability analysis for both instruments are summarized in Table 4.1.

TABLE 4.1

RELIABILITY RESULTS FOR LINGUISTIC INTELLIGENCE AND VAK QUESTIONNAIRES

\begin{tabular}{llll}
\hline & Item & case & Cronbach's Alpha \\
\hline Visual & 30 & 20 & 0.887 \\
Kinaesthetic & 30 & 20 & 0.724 \\
Auditory & 30 & 20 & 0.910 \\
Linguistic intelligence & 10 & 20 & 0.846 \\
\hline
\end{tabular}

As the reliability values reported in Table 4.1 indicate, the reliability coefficient for Visual, Kinaesthetic, and Auditory preferences of the participants in the pilot study turned out to be $.887, .724$, and .910 , respectively all of which are greater than the acceptable range of .7. Moreover, the reliability coefficient of the linguistic intelligence in the pilot study was obtained as .846 . Therefore, both instruments can be considered as completely reliable tools for eliciting the needed information from the main participants of the study.

Descriptive Statistics for VAK Preferences Scores

Table 4.2 shows descriptive statistics for Visual, Audio and Kinaesthetic Preferences scores.

TABLE 4.2

DESCRIPTIVE STATISTICS FOR VISUAL, AUDIO AND KINAESTHETIC PREFERENCES SCORES OF THE RESPONDENTS

\begin{tabular}{llllll}
\hline & $\mathrm{N}$ & Mean & Std. Deviation & Minimum & Maximum \\
\hline Visual & 100 & 8.77 & 1.96 & 5 & 13.00 \\
Kinaesthetic & 100 & 15.85 & 2.31 & 10 & 20.00 \\
Auditory & 100 & 5.45 & 2.66 & 1 & 12.00 \\
\hline
\end{tabular}


Table 4.2 indicates that the mean for Visual, Auditory, and Kinaesthetic preferences are 8.77, 15.85, and 5.45, respectively, and the standard deviation for the same items are 1.96, 2.31, and 2.66, respectively. Moreover, the descriptive statistics for the same participants in linguistic intelligence test are shown in Table 4.3.

TABLE 4.3

DESCRIPTIVE STATISTICS FOR LINGUISTIC INTELLIGENCE SCORES

\begin{tabular}{llllll}
\hline & $\mathrm{N}$ & Mean & Std. Deviation & Minimum & Maximum \\
\hline Linguistic Intelligence & 100 & 34.83 & 8.01 & 20 & 48.00 \\
\hline
\end{tabular}

Table 4.3 shows that the mean and standard deviation for linguistic intelligence are 34.83 and 8.01, respectively.

Testing the First Research Null Hypothesis

In order to test the first hypothesis claiming that there is not any significant relationship between linguistic intelligence and visual preferences of Iranian EFL learners, Pearson's correlation analysis was adopted the results of which are reported in Table 4.4 .

TABLE 4.4

CORRELATION BETWEEN LINGUISTIC INTELLIGENCE AND VISUAL PREFERENCES OF THE RESPONDENTS

\begin{tabular}{lll}
\hline & & Visual preference \\
\hline Linguistic Intelligence & Pearson Correlation & $.228^{*}$ \\
& Sig. (2-tailed) & .023 \\
& $\mathrm{~N}$ & 100 \\
\hline
\end{tabular}

As Table 4.4 indicates, there is a significant relationship between linguistic intelligence and visual preferences of Iranian school-level EFL learners $(r=.228, p=.023<.05)$. In other words, the higher the level of linguistic intelligence, the greater the learners' visual preference will be. Therefore, the first null hypothesis is safely rejected, meaning that there is a significant relationship between linguistic intelligence and visual preferences of Iranian EFL learners.

\section{Testing the Second Null Hypothesis}

As Table 4.5 shows, to test the validity of the second null hypothesis claiming that there is not any significant relationship between linguistic intelligence and auditory preferences of Iranian EFL learners, Pearson's correlation analysis was conducted too.

TABLE 4.5

CORRELATION BETWEEN LINGUISTIC INTELLIGENCE AND AUDITORY PREFERENCES OF THE RESPONDENTS

\begin{tabular}{lll}
\hline & & Auditory preference \\
\hline Linguistic Intelligence & Pearson Correlation & $-.486^{* *}$ \\
& Sig. (2-tailed) & .000 \\
& $\mathrm{~N}$ & 100 \\
\hline
\end{tabular}

Table 4.5 shows that there is a negative relationship between linguistic intelligence and auditory preferences of the respondents $(\mathrm{r}=.486, \mathrm{p}=.00<.05)$. In other words, the higher level of linguistic intelligence, the less the learners are likely to have auditory preferences. Therefore, the second null hypothesis is rejected as well, and there is a reverse significant relationship between linguistic intelligence and the auditory preferences of the respondents.

Testing the Third Correlational Hypothesis

To test the validity of the assumption in the third null hypothesis claiming the existence of no significant relationship between linguistic intelligence and Kinaesthetic preferences of Iranian EFL learners, the researcher conducted another Pearson's correlation analysis between the linguistic intelligence and the kinaesthetic preferences of the respondents the results of which are reported in Table 4.6.

TABLE 4.6

CORRELATIONS BETWEEN LINGUISTIC INTELLIGENCE AND KINAESTHETIC PREFERENCES OF THE RESPONDENTS

\begin{tabular}{lll}
\hline & & Kinesthetic Preferences \\
\hline linguistic intelligence & Pearson Correlation & $.404^{* *}$ \\
& Sig. (2-tailed) & .000 \\
& $\mathrm{~N}$ & 100 \\
\hline
\end{tabular}

Table 4.6 shows that that there is a significant relationship between linguistic intelligence and kinaesthetic learning preferences of the respondents $(r=.404, p=.00<.05)$. In other words, the higher level of linguistic intelligence, the more the learners will have kinaesthetic preferences. Therefore, the third null hypothesis is rejected as well.

\section{DISCUSSION}


The present study was launched with the purpose of examining the relationship between linguistic intelligence and the visual, auditory, and kinaesthetic preferences of Iranian EFL learners. Finding out about the mentioned issues is expected to have a beneficial effect on improving learning a new language since as stated by Fasold (1991), the ultimate purpose is helping the learners improve in any way possible.

The three null hypotheses on the non-existence of a significant relationship between linguistic intelligence and visual, auditory, and kinaesthetic preferences of Iranian EFL learners were rejected. It was found that linguistic intelligence is highly correlated with VAK preferences of the learners indicating that attending to personal preferences styles, and preferences of learners can play an accelerating role in improving the learners' linguistic intelligence. This is the point already endorsed by Brown (1987), Ellis (1994), Walqui (2000), Hoekstra (2009). All of the mentioned authors have emphasized the importance of attending to the learners' personality or learning styles in improving their learning. This also calls for the consideration of individual learning factors and individual instruction as stressed by Lyal (2002) and Dunn and Burke (2006) besides the others.

Although the second null hypothesis on the correlation between linguistic intelligence and auditory preferences of Iranian EFL learners was rejected, the correlation turned out to be negative, and the two variables had a reverse relationship with each other. In other words, with higher linguistic intelligence, the auditory preference scores were lower. This result, despite being surprising, has already been reported by Dilts, Epstein, Dilts (2011), Cetin (2009), Cronin and Myers (1997), and Canning (2000). Moreover, statistics have already shown that learners learn through visual modes of data about $60 \%$ of the times while learning through both auditory and kinaesthetic modes happens $20 \%$ of the times. This necessitates greater attention to the learners' visual preferences than their auditory or kinaesthetic preferences. Cetin (2009) endorses the point by saying that auditory learners exercise their vocal cords a lot; therefore, in one sense, they use kinaesthetic mode of learning as well.

In terms of the existence of a correlation between linguistic intelligence and VAK preferences, the findings of this study are in line with the findings of the study by Ahmadian and Hosseini (2012), Saricaoglu and Arikan's (2009), and Derakhshan and Faribi (2015). Alavinia and Ebrahimpour (2012) conducting a study on the relationship between emotional intelligence and learning styles of freshman Iranian EFL learners pointed to a positive meaningful relationship between emotional intelligence and learning styles. The significant correlation between different types of MI and the learners preferences has also already been pinpointed by some other authors including Prashnig (2005) and Shahi (2009).

The results of this study were also in line with the findings of Vaezi, (2015) who studied the relationship between Iranian EFL learners' and teachers' sensory preferences (visual, auditory, and kinaesthetic (VAK) and the learners' achievement in speaking. Results of the study indicated that matching Iranian EFL learners' and teachers' sensory preferences (VAK) had a significant effect on the learners' achievement in speaking. Similarly, the results of the study by Ahmadian and Hosseini (2012) showed that only linguistic intelligence and interpersonal intelligence had a statistically significant correlation with the participants' writing scores. Based on the results, the researchers showed that linguistic intelligence remains the best predictor of writing performance.

However, surprisingly enough, the results of the present study did not confirm the results obtained by Razmjoo (2008), and Sadeghi and Farzizadeh (2012) who found no significant correlation between linguistic intelligence and writing performance of Iranian EFL learners. Since in writing the learners do some sort of kinaesthetic activity, it is naturally expected that the higher the level of linguistic intelligence, the better writing performance; however, this expectation runs counter to the results obtained by the above-mentioned authors. This mismatch may result from difference in the language proficiency or age of the learners. This is endorsed by Pourhossein (2012) who found that Iranian EFL university student's preferred learning style was visual.

\section{CONCLUSION AND IMPLICATIONS}

As a conclusion, it can be suggested that the teacher should not refrain from exercising any effort to improve learning in his/her own particular situation within the post-method limitations of 'particularity, practicality', and 'possibility' (Kumaravadivelu, 2007). As emphasized by Carbo (1981), in this way the teacher will be in a better position to account for the needs of all learners. One way to address, individual learner needs is the use of individualized instruction (Dunn \& Burke, 2006). By matching the learners' different intelligence types (linguistic intelligence in this study) with their learning styles or learning preferences, the teacher can create a learning environment in which every individual learner flourishes. Furthermore, the results of the present study are still another confirmation for the fact that in this postmethod era of testing teaching should be shifted towards rather individualized form of education in which the educators cater for the needs, styles, and preferences of each individual learner. Finally, as the results of the present study clearly showed there is significant relationship between the Iranian EFL learners' level of linguistic intelligence and their visual, auditory, and kinaesthetic preferences. As such, the level of linguistic intelligence can serve as a good indicator of the learners' success in various visual, audio, and kinaesthetic learning tasks, and a teacher can opt for the learning activities that best suit the learners VAK preferences. It should be reiterated again that there is a negative relationship between the learners' linguistic intelligence and their auditory preference. In other words, the learners with higher linguistic intelligence are likely to have less interest on auditory input for their learning. 
By implication, language educators and teachers are advised to first estimate their learners' linguistic intelligence and adapt their teaching/learning tasks in a mood or style that suits their learning preferences. Parents should also attune their expectations of their learners' to their personality type features, learning styles, and preferences, and their expectations of their children should be realistic based on their learners' preferred learning styles. Moreover, school administrators should provide all the necessary equipment and facilities for the class and the EFL teacher to be able to tap each individual learner's preferred learning style. Furthermore, the local and global language education policy making bodies, curriculum developers, and syllabus designers are recommended to try to invest on the idea of individualized instruction. The one-size-fits-all approach to curriculum development and syllabus design fails to account for the needs of all types of learners having different learning styles and preferences. Last but not the least, the learners, with the help of their teachers, should develop an awareness of their own learning strategies, learning styles, and learning preferences so that they will opt for the learning techniques and strategies that correspond to their linguistic intelligence. This will be especially useful for the learners who learn the new language on a self-study basis.

Finally, the prospective researchers can focus their attention on some yet unexplored aspects of the title of this study. For example, this study just focused on the relationship between the learners' present level of linguistic intelligence and their VAK preferences; another study can be conducted to investigate the effect of linguistic intelligence training on VAK preferences of the learners. The relationship between personality type and VAK preferences of the EFL learners is another promising area of study. Predictability of VAK preferences through different types of intelligences is another path of research.

\section{APPENDIX I. LINGUISTIC INTELLIGENCE QUESTIONNAIRE}

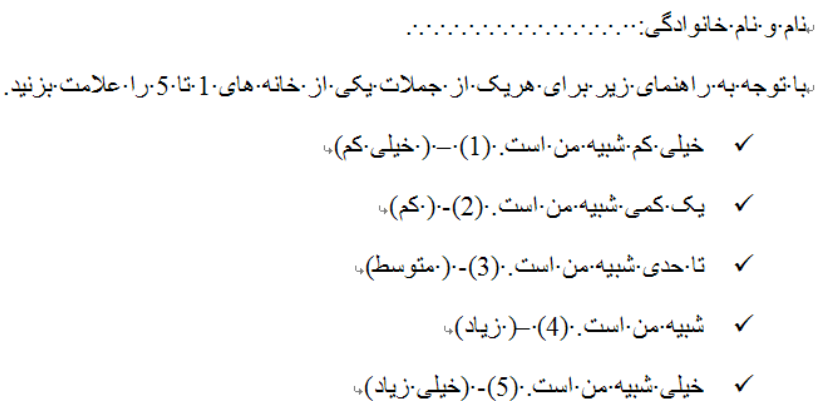

\begin{tabular}{|c|c|c|c|c|c|}
\hline 1 & 2 & 3 & 4 & 5 & \\
\hline & & & & & 1 \\
\hline & & & & & من اغر اقهاى زبانى ايهام اهنكهاى بى معنى و كلمات دو بهلو را دوست دارم. \\
\hline & & & & & 3. \\
\hline & & & & & 4. از اموزش دادن دانسته هايم به ديكر ان لذت ميبرم \\
\hline & & & & & 5. اغلب در مكالماتم به قِيز هايیى اشاره ميكنم كه قبلا ديده يا شنيده ام. \\
\hline & & & & & 6 6. اغلب افر اد معنى كلمات را از من مييرسند. \\
\hline & & & & & 7. من يك دفتر خاطر ات روز انه دارم تا اتفاقات زندكى ام را يادداشت كنم. \\
\hline & & & & & إخير اجيزى نوشته ام كه به ان افتخار ميكنم. 8 \\
\hline & & & & & 9. قبل از نوشنن خو اندن يا كفتن كلمات انها را در ذهنم ميشنوم. \\
\hline & & & & & در هنكام صحبت كردن تمايل دارم دستهاى خود ر ا تكان دهم و از زشت ها مانند تغير جهره استفاده كنم. \\
\hline
\end{tabular}

\section{APPENDIX II. VAK PREFERENCES QUESTIONNAIRE}

VAK Learning Styles Self-Assessment Questionnaire

Circle or tick the answer that most represents how you generally behave.

It's best to complete the questionnaire before reading the accompanying explanation.

1. When I operate new equipment I generally:

a. read the instructions first

b. listen to an explanation from someone who has used it before

c. go ahead and have a go, I can figure it out as I use it

2. When I need directions for travelling I usually:

a. look at a map

b. ask for spoken directions

c. follow my nose and maybe use a compass

3. When I cook a new dish, I like to:
a. follow a written recipe
b. call a friend for an explanation
c. follow my instincts, testing as I cook 
4. If I am teaching someone something new, I tend to:
a. write instructions down for them
b. give them a verbal explanation
c. demonstrate first and then let them have a go

5. I tend to say:
a. watch how I do it
b. listen to me explain
c. you have a go

6. During my free time I most enjoy:
a. going to museums and galleries
b. listening to music and talking to my friends
c. playing sport or doing DIY

7. When I go shopping for clothes, I tend to :
a. imagine what they would look like on
b. discuss them with the shop staff
c. try them on and test them out

8. When I am choosing a holiday I usually:
a. read lots of brochures
b. listen to recommendations from friends
c. imagine what it would be like to be there

9. If I was buying a new car, I would:

a. read reviews in newspapers and magazines

b. discuss what I need with my friends

c. test-drive lots of different types

10. When I am learning a new skill, I am most comfortable:
a. watching what the teacher is doing
b. talking through with the teacher exactly what I'm supposed to do
c. giving it a try myself and work it out as I go

11. If I am choosing food off a menu, I tend to:
a. imagine what the food will look like
b. talk through the options in my head or with my partner
c. imagine what the food will taste like

12. When I listen to a band, I can't help:
a. watching the band members and other people in the audience
b. listening to the lyrics and the beats
c. moving in time with the music

13. When I concentrate, I most often:
a. focus on the words or the pictures in front of me
b. discuss the problem and the possible solutions in my head
c. move around a lot, fiddle with pens and pencils and touch things

14. I choose household furnishings because I like:
a. their colours and how they look
b. the descriptions the sales-people give me
c. their textures and what it feels like to touch them

15. My first memory is of:
a. looking at something
b. being spoken to
c. doing something

16. When I am anxious, I:
a. visualise the worst-case scenarios
b. talk over in my head what worries me most
c. can't sit still, fiddle and move around constantly

17. I feel especially connected to other people because of:
a. how they look
b. what they say to me
c. how they make me feel

18. When I have to revise for an exam, I generally:
a. write lots of revision notes and diagrams
b. talk over my notes, alone or with other people
c. imagine making the movement or creating the formula 
19. If I am explaining to someone I tend to:
a. show them what I mean
b. explain to them in different ways until they understand
c. encourage them to try and talk them through my idea as they do it

20. I really love:

a. watching films, photography, looking at art or people watching

b. listening to music, the radio or talking to friends

c. taking part in sporting activities, eating fine foods and wines or dancing

21. Most of my free time is spent:
a. watching television
b. talking to friends
c. doing physical activity or making things

22. When I first contact a new person, I usually:
a. arrange a face to face meeting
b. talk to them on the telephone
c. try to get together whilst doing something else, such as an activity or a meal

23. I first notice how people:
a. look and dress
b. sound and speak
c. stand and move

24. If I am angry, I tend to:
a. keep replaying in my mind what it is that has upset me
b. raise my voice and tell people how I feel
c. stamp about, slam doors and physically demonstrate my anger

25. I find it easiest to remember:
a. faces
b. names
c. things I have done

26. I think that you can tell if someone is lying if:
a. they avoid looking at you
b. their voices changes

27. When I meet an old friend:
a. I say "it's great to see you"!
b. I say "it's great to hear from you"!
c. I give them a hug or a handshake

28. I remember things best by:

a. writing notes or keeping printed details

b. saying them aloud or repeating words and key points in my head

c. doing and practising the activity or imagining it being done

29. If I have to complain about faulty goods, I am most comfortable:
a. writing a letter
b. complaining over the phone
c. taking the item back to the store or posting it to head office

30. I tend to say:

a. I see what you mean

b. I hear what you are saying

c. I know how you feel

Now add up how many A's, B's and C's you selected.
A's =
B's =
C's

If you chose mostly A's you have a VISUALlearning style.

If you chose mostly B's you have an AUDITORY learning style.

If you chose mostly C's you have a KINAESTHETIC learning style.

\section{REFERENCES}

[1] Ahmadian, M., \& Hosseini, S. (2012). A study of the relationship between Iranian EFL learners Multiple Intelligences and their performance on writing. Mediterranean Journal of Social Sciences, 3 (1). Doi:10.5901/mjss.2012.03.01.111.

[2] Alavinia, P., \& Ebrahimpour, S. (2012). On the correlation between emotional intelligence and learning styles: the case of Iranian academic Eel learners, Theory and Practice. Language Studies,2(6),1291-1299. 
[3] Brown, B. L (1996). Learning styles and vocational education practice. U.S. Department of Education, Office of Educational Research and Improvement, Practice Application Briefs.

[4] Canning, C. (2000). Visual research. Invited presentation for the TESOL Arabia Special Interest Group, Hilton Ballroom.

[5] Carbo, M. (1981). Reading Style Inventory Manual. New York: Learning Research Associates.

[6] Çetin, Y. (2009). Teaching VAK-abulary. Paper presented at the 1st International Symposium on Sustainable Development, Sarajevo, Bosnia and Herzegovina.

[7] Christison, M. A. (1998). Multiple Intelligences. ESL Magazine, 2(5), 10-13.

[8] Cronin, M. \& Myers S. (1997). The effects of visuals versus no visuals on learning outcomes from Interactive multimedia instruction, Journal of Computing in Higher Education. 8(2),46-71

[9] Davoudi, M. \& Chavosh, M. (2016). The Relationship between multiple intelligences and listening self-efficacy among Iranian EFL learners. English Language Teaching, 9(6), 199-200.

[10] Dehghan Harati, R. (2011). Learner beliefs, teacher beliefs: Are they different? Iranian EFL Journal, 7(5), 190-221.

[11] Derakhshan, A. \& Faribi, M. (2015). Multiple intelligences: Language learning and teaching. International Journal of English Linguistics, 5(4), 16-19.

[12] Dilts, R. D. \& Epstein, T., Dilts R., W. (2011). NLP and the creativity. Alessio Roberti, Roma, Italy.

[13] Dunn, R. \& Burke, K. (2006). Research and implementation manual. International Learning Styles Network. Available at http//:www.learningstyles.net/En/user-home (2016).

[14] Ellertone, R., (2015) NLP and Personal Growth Thoughts. Renewal Technologies Inc, 1(2).

[15] Ellis, R. (1994). The study of second language acquisition. Oxford: Oxford University Press.

[16] Farooque, I., Mustafa, S., \& Mohammad, F. (2014). Learning style preferences of first year undergraduate medical students. $J$ Evid Based Med Health, 1, 1445-52.

[17] Fasold, R. (1991). The sociolinguistics of society. Oxford: Basic Blackwell.

[18] Gardner, H. (1983). Frames of mind: The theory of multiple intelligences. New York: Basic books.

[19] Hoekstra, K. (2009). Problem Solvers. A Greener Greendale. Teaching Children Mathematics, 16(3), 140-143.

[20] Kumaravadivelu, B. (2006). Understanding language teaching. Lawrence Earlbaum Associates Inc. Publishers: NJ, USA.

[21] Lyall, D. (2002). NLP in Training: the power to facilitate. Training Journal November Issue, pp. 1219.

[22] Marwaha1, K., Bhagat, A. \& Kapoor, N. (2015). Learning style preferences of undergraduate dental students of a north Indian dental college. Indian Journal of Physiology Pharmacology, 59(32), 231-237.

[23] Merritt, A. (2013). Why learn a foreign language? Benefits of bilingualism. The Telegraph, Retrieved from $\mathrm{http} / /$ www.telegraph.co.uk/education/educationopinion/10126883/Why-learn-aforeign-language-Benefits-of-bilingualism.html (2016).

[24] Mohammadi, M., \& Mousalou, R. (2012).Emotional intelligence, Linguistic intelligence, and their relevance to speaking anxiety of EFL learners. Journal of Academic and Applied Studies, 2(6), 11- 22.

[25] Pourhossein Gilakjani, A. (2012). Visual, Auditory, Kinesthetic Learning Styles and Their Impacts on English Language Teaching. Unpublished M.A. Thesis, Islamic Azad University- Lahijan Branch.

[26] Po-Ying, (1999). Multiple intelligences theory and English language teaching. Department of English, NCCU. Retrieved from http://highschool.english.nccu.edu.tw/p, 2017.

[27] Prashnig, B. (2005). Learning styles vs. multiple intelligences. Retrieved from www.creativelearningcentre.com/.../ArticleLearning-Styles-vs-html (2016).

[28] Razmjoo, S. A. (2008). On the relationship between multiple intelligences and language proficiency. The Reading Matrix, 8(2), 155-174.

[29] Richards, J. C. \& Schmidt, R. (2002). Longman Dictionary of Language Teaching and Applied Linguistics, Pearson Education Limited: UK.

[30] Sadeghi, K., \& Farzizadeh, B. (2012).The relationship between multiple intelligences and writing ability of Iranian EFL learners. English Language Teaching, 5(11), 136-142.

[31] Saeidi, M. (2007). Multiple intelligence-based focus on form: From theory to practice, Tabriz: Islamic Azad University Tabriz Branch.

[32] Sajjadi Rad, R. Khojasteh, L. \& Kafipour, R. (2015). The relationship between multiple intelligence and writing skills of medical students in Iran. Acta Didactica Napocensia, 7(3), 9-11.

[33] Saricaoglu, A., \& Arikan, A. (2009). A study of multiple intelligences, foreign language success and some selected variables. Journal of Theory and Practice in Education, 5(2), 110-122.

[34] Shahi, H. (2009). The relationship between multiple intelligence and learning styles. Unpublished M.A. Thesis, University of Kashan.

[35] Vaezi, Sh. (2015), Iranian EFL learners' and teachers' sensory preferences and the learners' speaking ability. International Journal of English Language Education, 3(2), 14-27

[36] Walqui, A. (2000). Contextual factors in second language acquisition. ERIC Clearinghouse on Languages and Linguistics, Center for Applied Linguistics.

[37] Yall, D. (2002). NLP in Training: the power to facilitate. Training Journal November Issue, pp. 1219. 


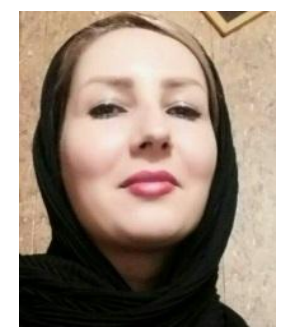

Rashideh Zoghi has BA in Art and Craft and M.A. in TEFL. She is TKT certified too. She is a teacher, sub head of Department of English Teachers in East Azerbaijan, Tabriz, Iran and supervisor in New Talent Cambridge Preparation Center in Tabriz. Her main interests are neuro linguistic programming (NLP), accelerated learning, creative teaching techniques, personality types and corrective feedback. She has been teaching in Iranian state and private secondary schools since 2002, international language institute, and Farhangian university of Tabriz. 